\title{
CTAG1B Gene
}

National Cancer Institute

\section{Source}

National Cancer Institute. CTAG1B Gene. NCI Thesaurus. Code C39285.

This gene plays a role in humoral and cellular immune responses. 